\title{
FAKTOR-FAKTOR YANG MEMPENGARUHI PEMILIHAN PROFESI AKUNTANSI OLEH MAHASISWA AKUNTANSI
}

\author{
Laela Putri Lestari \\ Yefta Andi Kus Noegroho \\ Akuntansi, Universitas Kristen Satya Wacana, Salatiga, Indonesia
}

\section{Info Artikel}

\section{Sejarah Artikel:}

Diterima : 12 Juli 2019

Disetujui : 5 Oktober 2019

Dipublikasikan : 1 Januari 2020

\section{Keywords:}

Accounting Student;

Accounting Profession

Selection;

Discriminant Analysis.

\begin{abstract}
Abstrak


mahasiswa Akuntansi dalam pemilihan karir sebagai akuntan. Sampel yang digunakan sebanyak 119 mahasiswa angkatan 2015 sampai 2018 dan masih aktif pada tahun 2018 dengan teknik pengambilan sampel berupa metode convenience sampling. Teknik pengambilan data menggunakan kuesioner yang dibagikan secara langsung dan dianalisis menggunakan teknik analisis diskriminan. Hasil penelitian menunjukkan variabel pelatihan profesional, nilai sosial dan pertimbangan pasar kerja berpengaruh terhadap pemilihan karir sebagai akuntan. Sedangkan variabel penghargaan finansial, pengakuan profesional, lingkungan kerja dan personalitas tidak berpengaruh dalam pemilihan karir sebagai akuntan. Profesi yang paling banyak dipilih adalah profesi akuntan internal atau perusahaan.
\end{abstract}

\section{Abstract}

The research aims to test factors influencing students in accounting majors in the election career as an accountant. Samples were used as many as 119 students of 2015 to 2018 and were still active in 2018 with sampling techniques in the form of convenience sampling. Data retrieval techniques use questionnaires directly shared and analyzed using discriminant analysis techniques. The results of the study showed professional training variables, social value and job market considerations affecting career selection as an accountant. While the variable financial awards, professional recognition, work environment and personality have no effect in the career selection as an accountant. The most widely chosen profession is the profession of an internal accountant or company.

\footnotetext{
Alamat korespondensi :

J1. Diponegoro 52-60 Salatiga - Indoensia 50711

E-mail: 232015100@student.uksw.edu 


\section{PENDAHULUAN}

Hal umum yang mendasari mahasiswa berminat memilih program studi akuntansi adalah karir di bidang akuntansi. Tidak dapat dipungkiri bahwa tujuan lain mahasiswa pada pemilihan tersebut bisa saja digunakan sebagai batu loncatan untuk mendapatkan karir yang lebih baik di bidang non akuntansi. Ketua Dewan Pengurus Nasional IAI, Prof. Mardiasmo, CA mengatakan, bahwa Indonesia setiap tahunnya meluluskan lebih dari 35.000 mahasiswa akuntansi (IAI 2016). Lulusan mahasiswa akuntansi dari 35.000 orang tersebut hanya sekitar 24.000 saja yang tercatat sebagai akuntan profesional di Ikatan Akuntansi Indonesia (IAI 2016). Walaupun tiap tahunnya lulusan mahasiswa akuntansi tinggi, namun kenyataannya lulusan yang berminat untuk menekuni profesi akuntansi tidak sebanyak lulusannya. Hal tersebut dikarenakan adanya kemungkinan persebaran yang tidak merata pada profesi akuntansi lainnya.

Saat ini perkembangan dunia bisnis di Indonesia sangat pesat yang menyebabkan munculnya berbagai macam lapangan pekerjaan bagi angkatan kerja khususnya di bidang akuntansi. Lapangan pekerjaan di bidang akuntansi sekarang ini sudah banyak dan memadai bagi lulusan mahasiswa akuntansi. Hal itu terjadi karena akuntansi sangat dibutuhkan, di samping kemajuan teknologi yang semakin berkembang. Terbukti dari kebutuhan akuntan berstandar internasional di Indonesia menurut Manish Gidwani selaku $C E O$ dan Founder LSAF Global sebanyak 452.000, sedangkan data dari PPAJ (Pusat Pembinaan Akuntan dan Jasa Penilai) Kementrian Keuangan Republik Indonesia hanya berkisar 16.000 akuntan profesional (Munjin 2018). Memadainya lapangan pekerjaan tidak akan menjamin menutup kekurangan tenaga akuntan profesional yang dibutuhkan di Indonesia. Minimnya pengetahuan akan informasi lapangan pekerjaan membuat lulusan mahasiswa akuntansi memilih alternatif pekerjaan di bidang non akuntansi.

Tahap awal lulusan mahasiswa akuntansi sebelum memasuk dunia kerja adalah pemilihan karir. Pemilihan karir tersebut berdasarkan minat dalam diri mahasiswa dengan berbagai pertimbangan. Pemilihan karir merupakan perjalanan individu dalam mempersiapkan diri untuk memasuki dunia kerja melalui suatu rangkaian proses kegiatan yang terarah dan sistematis (Dwi and Setiawan 2012). Bidang akuntansi memiliki beragam karir yang dapat dijadikan pilihan oleh lulusan mahasiswa akuntansi yaitu, akuntan pemerintah, akuntan pendidik, akuntan perusahaan dan akuntan publik (Chan 2012). Pemilihan karir yang tepat dilakukan mahasiswa agar dapat merubah masa depan manjadi lebih baik. Karir yang didapat merupakan tolak ukur keberhasilan mahasiswa dalam menempuh jenjang pendidikan di perguruan tinggi.

Merdekawati and Sulistyawati (2011)dalam penelitiannya menyatakan bahwa pemilihan karir akuntan publik dan non akuntan publik dipengaruhi oleh beberapa faktor. Penelitian tersebut menggunakan metode berupa analisis regresi logistik terhadap variabel penghargaan finansial, pelatihan profesional, pengakuan profesional, nilai sosial, lingkungan kerja, pertimbangan pasar kerja dan personalitas. Hasil yang diperoleh adalah penghargaan finansial berupa gaji awal yang tinggi, potensi kenaikan gaji dan tersedianya dana pensiun ternyata tidak memiliki pengaruh yang signifikan terhadap pemilihan karir akuntan. Berbeda dengan hasil penelitian Dianati (2017) yang menggunakan metode analisis regresi linier berganda bahwa penghargaan finansial dengan 
penambahan indikator adanya tunjangan lainnya memiliki pengaruh signifikan terhadap minat mahasiswa akuntansi berkarir sebagai akuntan publik.

Pelatihan profesional yang terdiri dari pelatihan kerja sebelum mulai kerja, latihan di luar lembaga untuk meningkatkan profesionalitas, pelatihan rutin di dalam lembaga dan pengalaman kerja yang bervariasi dalam penelitian Merdekawati and Sulistyawati (2011) memiliki pengaruh yang signifikan terhadap pemilihan karir akuntan. Hasil ini berbeda dengan penelitian yang dilakukan oleh Dianati (2017) yang menyatakan variabel pelatihan profesional dengan indikator yang sama namun tidak memiliki pengaruh yang signifikan terhadap minat mahasiswa berkarir sebagai akuntan publik. Perbedaan hasil ini juga terjadi dalam variabel pengakuan profesional berupa kesempatan untuk berkembang, pengakuan apabila berprestasi, cara untuk naik pangkat dan keahlian tertentu untuk meraih sukses oleh Merdekawati and Sulistyawati (2011) memiliki pengaruh yang signifikan terhadap pemilihan karir akuntan, sedangkan variabel tersebut dengan perbedaan indikator berupa memiliki keahlian khusus tidak memiliki pengaruh yang signifikan (Dianati 2017).

Talamaosandi and Wirakusuma (2017) menjelaskan bahwa nilai sosial meliputi kesempatan untuk berinteraksi dengan orang lain, kesempatan menjalankan hobi, pekerjaan yang bergengsi dan kesempatan bekerja dengan ahli bidang lain mempunyai pengaruh yang signifikan positif pada pemilihan karir sebagai akuntan publik. Selain itu nilai sosial juga meliputi kesempatan untuk pelayanan sosial dan perhatian terhadap perilaku individu juga berpengaruh signifikan positif pada pemlihan karir sebagai akuntan publik (Merdekawati and Sulistyawati 2011). Pertimbangan pasar kerja dalam penelitian Talamaosandi and Wirakusuma (2017) menyatakan bahwa keamanan kerja dan tersedianya lapangan kerja atau kemudahan mengakses lowongan pekerjaan berpengaruh signifikan pada pemilihan karir sebagai akuntan publik. Hasil tersebut bertolak belakang dengan penelitian Merdekawati and Sulistyawati (2011) bahwa pertimbangan pasar kerja tidak berpengaruh signifikan.

Talamaosandi and Wirakusuma (2017) menjelaskan bahwa lingkungan kerja meliputi rutin, atraktif, sering lembur dan adanya tekanan kerja ternyata berpengaruh signifikan positif pada pemilihan karir sebagai akuntan publik. Pekerjaan yang lebih cepat diselesaikan, banyak tantangan, lingkungan kerja yang menyenangkan serta kompetisi antar karyawan juga memiliki pengaruh yang signifikan (Dianati 2017). Hasil penelitian Merdekawati and Sulistyawati (2011) dengan indikator yang sama pada kedua penelitian di atas namun hasilnya menyatakan lingkungan kerja tidak berpengaruh signifikan terhadap pemilihan karir akuntan. Kejadian hasil yang berbeda juga terjadi dalam variabel personalitas oleh Talamaosandi and Wirakusuma (2017) dinyatakan dengan sesuatu yang mencerminkan personalitas seseorang yang bekerja secara profesional berpengaruh signifikan positif pada pemilihan karir sebagai akuntan publik. Penelitian Dianati (2017) menjelaskan bahwa personalitas meliputi sikap profesional dalam bekerja, pekerjaan sesuai dengan harapan, mengharapkan gaji yang tinggi, memiliki sikap berwibawa dan memiliki ciri khas tersendiri juga berpengaruh signifikan terhadap minat mahasiswa akuntansi berkarir sebagai akuntan publik. Namun, hasil yang berbeda ditemukan pada penelitian Merdekawati and Sulistyawati (2011) yang menyatakan personalitas berupa kesesuaian pekerjaan dengan kepribadian yang dimiliki seseorang tidak 
berpengaruh yang signifikan terhadap pemilihan karir akuntan.

Berdasarkan penelitian sebelumnya, terdapat beberapa perbedaan pada alat ukur dan metode yang dipakai sehingga mempengaruhi hasil penelitian. Perbedaan di atas menjadi dasar peneliti untuk mengkaji ulang dan melihat konsistensi dari penelitian sebelumnya. Dalam penelitian ini menggunakan ketujuh variabel dari Merdekawati and Sulistyawati (2011) yaitu penghargaan finansial, pelatihan profesional, pengakuan profesional, nilai sosial, lingkungan kerja, pertimbangan pasar kerja dan personalitas dengan mengembangkan alat ukur pada beberapa variabel. Penelitian ini juga menggunakan beberapa pilihan jenis profesi akuntansi sebagai variabel terikat. Tingginya lulusan mahasiswa akuntansi diiringi dengan menurunnya minat terhadap profesi akuntansi, akan berakibat pada banyaknya lapangan pekerjaan yang terabaikan. Atas dasar tersebut tidak menutup kemungkinan kekurangan tenaga akuntan profesional di Indonesia berkurang. Profesi akuntansi di Indonesia beberapa tahun yang akan datang bisa terancam punah karena semakin menurunnya minat mahasiswa terhadap profesi akuntansi dari tahun ke tahun.

Adapun fokus dari penelitian ini adalah ingin melihat pengaruh beberapa variabel yaitu penghargaan finansial, pelatihan profesional, pengakuan profesional, nilai sosial, lingkungan kerja, pertimbangan pasar kerja, personalitas terhadap pemilihan profesi akuntani dan melihat persebaran profesi akuntansi menurut responden. Penelitian ini bertujuan untuk menguji faktor-faktor yang mempengaruhi mahasiswa dalam pemilihan karir sebagai akuntan. Hasil dari penelitian ini diharapkan agar pemerintah sebagai regulator bisa mengantisipasi perkembangan jumlah anggota profesi di bidang akuntansi atau mengantisipasi kekurangan akuntan profesional di masa depan dan untuk pelaksana pendidikan tinggi di bidang akuntansi bisa memodifikasi atau melakukan inovasi perbaikan dalam proses pembelajaran supaya minat mahasiswa terhadap profesi akuntansi meningkat.

\section{Kajian Literatur}

Teori Pengharapan ialah kehendak yang kuat dalam bertindak menggunakan cara khusus yang bergantung pada kekuatan atau besarnya harapan atas tindakan yang dilakukan akan memberikan hasil tertentu untuk setiap individu (Robbin 2001). Seseorang akan melakukan sesuatu atas dasar harapan besar dalam dirinya untuk mendapatkan hasil yang baik dengan usaha yang semaksimal mungkin. Usaha tersebut akan dinilai baik ketika pencapaian hasilnya sesuai dengan target bahkan melampaui dan tentunya mereka akan mendapatkan reward atas usaha tersebut.

$$
\text { Menurut Hudayati (2002) }
$$

pengharapan ditentukan oleh dua faktor yaitu expectancies dan valences. Expectancies adalah keyakinan ketika memutuskan sikap tertentu akan memberikan hasil tertentu. Valences berarti penilaian atas hasil atau rewards yang diberikan dan diterima oleh individu. Contohnya seperti seseorang bekerja lebih giat dan tekun agar mendapatkan kenaikan gaji dari tempatnya bekerja. Merdekawati and Sulistyawati (2011) mengungkapkan bahwa pengharapan mempengaruhi sikap seseorang yang terbentuk dari tiga komponen, yaitu cognitive component, emotional component dan behavioral component. Cognitive component, perasaan seseorang menyukai sesuatu yang bersifat emosi dan orang tersebut akan cenderung mendapatkannya jika menginginkan sesuatu. Behavioral component ialah tindakan khusus yang dilakukan dalam menanggapi peristiwa 
dan informasi asing, sehingga seseorang mempunyai dorongan agar berusaha lebih keras karena keyakinan akan usaha tersebut tidak akan mengecewakan.

Seseorang dalam menentukan kehidupan mendatang tak lepas dari pekerjaan yang ditekuninya saat ini. Pekerjaan atau profesi sebenarnya adalah sebagai wadah untuk berkembang dan menghidupi diri seseorang tersebut. Penentuan pekerjaan tentunya diharapkan memberikan hasil yang menguntungkan untuk kehidupannya. Perilaku seseorang dalam menentukan profesi disebabkan karena adanya dorongan dalam dirinya untuk menjadi lebih baik. Berbagai faktor juga muncul dalam mempengaruhi harapan seseorang selain dorongan diri sendiri. Faktor-faktor yang dimaksudkan dalam penelitian ini adalah penghargaan finansial, pelatihan profesional, pengakuan profesional, nilai sosial, lingkungan kerja, pertimbangan pasar kerja, dan personalitas.

\section{Model Penelitian}

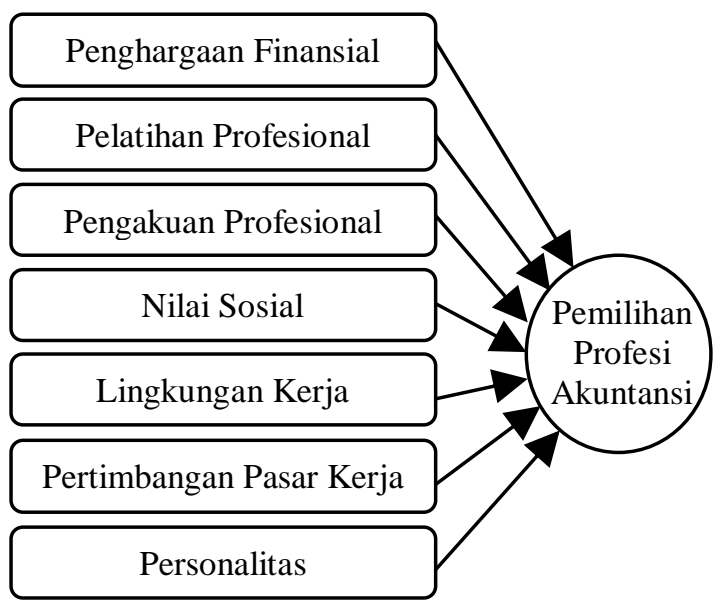

Gambar 1. Model Penelitian

\section{Pengaruh Penghargaan Finansial Terhadap Pemilihan Profesi Akuntansi}

Gaji atau penghargaan finansial bagi seseorang dalam memilih pekerjaan menjadi pertimbangan utama. Adanya pertimbangan tersebut dikarenakan seseorang memiliki harapan untuk mendapat pekerjaan dengan gaji yang sesuai dengan kemampuan yang dimiliki.
Dengan memperoleh gaji tersebut seseorang juga berharap dapat memenuhi kebutuhannya. Penelitian Yanti (2017) menghasilkan bahwa penghargaan finansial berpengaruh terhadap pemilihan karir akuntan publik. Hal tersebut didukung oleh penelitian yang dilakukan oleh Dianati (2017), Rahayu, Sudaryono, and Setiawan (2003) dan Riyanto (2015). Yusran (2017) menyimpulkan bahwa pengahargaan finansial atau gaji merupakan hal utama yag mendasar dan menjadi harapan mahasiswa dalam memperoleh karir yang bagus dengan gaji yang sesuai tingkat pendidikan dan ketrampilan yang mereka punya. Karna semakin tinggi gaji yang ditawarkan, maka pengaruhnya akan semakin besar terhadap kemungkinan suatu pekerjaan akan dipilih. Bukan hanya gaji yang mereka harapkan namun juga adanya tunjangan serta dana pensiuan yang diterima dari tempat dimana mereka bekerja. Mahasiswa yang memilih profesi akuntan pemerintah dan akuntan pendidik sangat mengharapkan dana pensiun, berbeda dengan mahasiswa yang memilih profesi akuntan perusahaan dan akuntan publik kurang mengharapkan adanya dana pensiun (Rahayu, Sudaryono, and Setiawan 2003). Berdasarkan uraian di atas, maka dapat dirumuskan hipotesis sebagai berikut :

H1 : Penghargaan Finansial di bidang akuntansi berpengaruh terhadap pemilihan profesi akuntansi.

\section{Pengaruh Pelatihan Profesional Terhadap Pemilihan Profesi Akuntansi}

Bekerja disuatu organisasi atau perusahaan tidak cukup bermodalkan pengetahuan yang dimiliki, namun juga diperlukan adanya keterampilan yang profesional. Hal tersebut dapat diperoleh dengan mengikuti pelatihan yang ada di dalam dan di luar organisasi atau perusahaan. Hasil penelitian Chan (2012) dan Merdekawati and Sulistyawati (2011) mengatakan bahwa pelatihan profesioanl 
berpengaruh signifikan terhadap minat menjadi akuntan publik. Semakin banyak megikuti pelatihan-pelatihan maka keterampilan yang dimiliki akan semakin terasah. Dampaknya akan dapat mempengaruhi kinerja di suatu organisasi atau perusahaan. Ramdhan and Widaningsih (2017) menyatakan bahwa mahasiswa yang memilih profesi akuntan publik mempunyai pemikiran lebih membutuhkan pelatihan sebelum bekerja yang didapat dari luar maupun di tempat bekerja dan mendapatkan pengalaman kerja yang beragam, sedangkan mahasiswa yang memilih profesi non akuntan publik tidak memiliki pemikiran tersebut. Perlunya pelatihan ini dikarenakan mahasiswa beranggapan di bangku perkuliahan hanya memperolah pengetahuan sebatas teori saja, maka mereka memiliki pemikiran dibutuhkannya pelatihan yang profesional. Berdasarkan uraian di atas, maka dapat dirumuskan hipotesis sebagai berikut :

H2 : Pelatihan Profesional di bidang akuntansi berpengaruh terhadap pemilihan profesi akuntansi.

\section{Pengaruh Pengakuan Profesional Terhadap Pemilihan Profesi Akuntansi}

Prestasi merupakan tingkat keberhasilan seseorang dalam menguasai pengetahuan yang diperoleh. Tentunya hampir semua orang akan merasa senang dengan pujian atau pengakuan atas prestasi yang diraihnya. Pengakuan ini juga akan mempengaruhi seseorang dalam melakukan pekerjaanya, seperti perasaan bangga hingga munculnya semangat untuk lebih berprestasi. Penelitian Yanti (2017) membuktikan bahwa pengakuan profesional berperngaruh terhadap pemilihan karir akuntan publik. Hasil penelitian yang sama juga diperoleh Riyanto (2015) dan Merdekawati and Sulistyawati (2011). Senoadi (2015) menyatakan bahwa adanya kepuasan tersendiri saat mendapatkan pengakuan profesional atau prestasi kerja dalam berkarir, mengingat keahlian tertentu itu dibutuhkan, jangka waktu yang lama dan jenjang karir yang panjang. Mahasiswa akuntansi beranggapan jika bekerja sebagai akuntan publik tidak hanya mendapat pengakuan prestasi namun juga kesempatan berkembang karena memerlukan keahlian tertentu di bidang akuntansi untuk mencapai jenjang karir lebih tinggi (Siskayani and Saitri 2013). Berdasarkan uraian di atas, maka dapat dirumuskan hipotesis sebagai berikut :

H3 : Pengakuan Profesional di bidang akuntansi berpengaruh terhadap pemilihan profesi akuntansi.

\section{Pengaruh Nilai Sosial Terhadap Pemilihan Profesi Akuntansi}

Nilai sosial merupakan cara pandang masyarakat mengenai baik dan buruknya suatu jenis profesi. Masyarakat akan menilai baik suatu profesi akuntan jika seorang akuntan memenuhi penilaian dan sebaliknya akan dinilai buruk jika akuntan bekerja tidak sesuai dengan semestinya. Menurut Siskayani and Saitri (2013) nilai sosial akan mendorong profesi akuntan lebih dihargai dan memperoleh tempat di tingkat sosial masyarakat. Sikap peduli dan perhatian terhadap sekitar yang dimiliki seorang akuntan dapat meningkatkan nilai intrinsik serta nilai jual akuntan (Senjari 2016). Hasil penelitian Riyanto (2015) yang menyatakan bahwa nilai sosial berpengaruh terhadap minat mahasiswa akuntan berkarir menjadi akuntan publik. Penelitian Purwati and Sari (2015) juga mengatakan hal yang sama, bahkan bukan hanya pada karir akuntan publik namun juga terhadap karir non akutan publik. Nilai-nilai sosial yang berpengaruh ini menunjukkan adanya penilaian yang adil bahwa profesi akuntan publik, akuntan pendidik, akuntan perusahaan maupun akuntan pemerintah memegang nilai-nilai sosial dalam pekerjaannya (Merdekawati 
and Sulistyawati 2011). Berdasarkan uraian di atas, maka dapat dirumuskan hipotesis sebagai berikut :

$H 4$ : Nilai Sosial di bidang akuntansi berpengaruh terhadap pemilihan profesi akuntansi.

Pengaruh Lingkungan Kerja Terhadap Pemilihan Profesi Akuntansi

Lingkungan kerja yang nyaman memiliki peran untuk mempengaruhi seseorang dalam memilih suatu pekerjaan. Dalam hal ini, kinerja karyawan juga bergantung dengan suasana sekitar ditempatnya bekerja. Semakin seseorang nyaman dengan lingkungan kerja termasuk dengan pekerjaan yang dilakukannya, maka seseorang tersebut akan merasa betah di tempat mereka bekerja. Dianati (2017) membuktikan bahwa lingkungan kerja berpengaruh signifikan terhadap minat mahasiswa akuntansi berkarir sebagai akuntan publik. Penelitian tersebut didukung oleh Ramdhan and Widaningsih (2017) menyebutkan bahwa mahasiswa yang memilih profesi akuntan publik mempunyai pemikiran bahwa profesi yang dipilih memiliki pekerjaan yang tidak teratur, lebih atraktif atau banyak tantangan dan selalu lembur. Mahasiswa akuntansi dengan jiwa kompetensi yang tinggi lebih memilih lingkungan pekerjaan yang rutin memberikan tantangan dan menyebabkan mahasiswa mendapatkan kepuasan tersendiri ketika mampu menyelesaikan tantangan dengan baik (Siskayani and Saitri 2013). Berdasarkan uraian di atas, maka dapat dirumuskan hipotesis sebagai berikut :

H5 : Lingkungan Kerja di bidang akuntansi berpengaruh terhadap pemilihan profesi akuntansi.

Pengaruh Pertimbangan Pasar Kerja Terhadap Pemilihan Profesi Akuntansi

Pertimbangan pasar kerja merupakan salah satu faktor yang melatarbelakangi mahasiswa dalam memilih profesi bidang akuntansi. Hal ini dikarenakan mahasiswa memiliki pemikiran bahwa semakin banyak lapangan pekerjaan suatu profesi, maka peluang akan mendapatkan pekerjaan yang layak semakin besar. Setiap pekerjaan memiliki peluang yang berbeda-beda dan hal tersebut oleh mahasiswa menjadi pertimbangan. Penelitan yang dilakukan oleh Purwati and Sari (2015) menghasilkan bahwa pertimbangan pasar kerja berpengaruh dan menjadi dasar pertimbangan dalam memilih karir di bidang akuntansi. Hasil tersebut didukung oleh penelitan Ramdhan and Widaningsih (2017) dan Harianti (2017) . Hasil penelitian di atas menunjukkan bahwa pertimbangan pasar kerja mempengaruhi mahasiswa dalam memilih profesi yang akan dijalani untuk karir kedepannya. Berdasarkan uraian di atas, maka dapat dirumuskan hipotesis sebagai berikut :

H6 : Pertimbangan Pasar Kerja di bidang akuntansi berpengaruh terhadap pemilihan profesi akuntansi.

\section{Pengaruh Personalitas Terhadap Pemilihan Profesi Akuntansi}

Personalitas yang dimiliki seseorang merupakan cerminan dirinya dalam menanggapi apa yang terjadi di lingkungan sekitarnya. Dari lima faktor kepribadian yang dikemukakan oleh McCrae and Costa (1989) akan dilihat mana yang paling menonjol pada seseorang yang nantinya akan berpengaruh pada pemilihan profesi akuntansi oleh mahasiswa. Nasyroh and Wikansari (2017) membuktikan dua diantara lima dimensi kepribadian yaitu neuriticism dan agreeableness memiliki hubungan yang paling signifikan. Penelitian Nasyroh and Wikansari (2017) terhadap kinerja karyawan suatu PT tersebut menghasilkan bahwa neuriticism berperan serta pada hasil kinerja terkait kualifikasi pekerjaan mengenai deadline dan target (Nasyroh and Wikansari 2017). Faktor agreeableness juga berpengaruh 
terhadap kinerja karyawan karena semakin tinggi agreeableness akan mempunyai sikap kooperatif dalam bekerja, mudah percaya, hangat dan ramah (Nasyroh and Wikansari 2017).

Hasil penelitian Chan (2012) juga membuktikan bahwa personalitas berpengaruh signifikan terhadap minat menjadi akuntan publik. Hasil tersebut ditemukan pula dalam penelitian Dianati (2017) yang menunjukkan jika personalitas semakin sesuai dengan kepribadian seseorang akan berdampak pada meningkatnya minat mahasiswa akuntansi terhadap karir akuntan publik. Mahasiswa akuntansi yang terus menerus mengejar kesempurnaan mengharapkan pengakuan prestasi yang dimiliki, menuntut loyalitas, serta menyukai tantangan dan mendapatkan tugas yang sulit biasanya memilih karir akuntan publik (Siskayani and Saitri 2013). Personalitas mempunyai pengaruh terhadap pemilihan profesi akuntansi juga didukung oleh penelitian Suyono (2014) dan Sudarsono (2014). Berdasarkan uraian di atas, maka dapat dirumuskan hipotesis sebagai berikut :

$H 7$ : Personalitas di bidang akuntansi berpengaruh terhadap pemilihan profesi akuntansi.

\section{METODE}

\section{Desain Penelitian}

Jenis penelitian ini
dikelompokkan dalam penelitian survei dengan tujuan untuk mendapatkan informasi dari responden menggunakan kuesioner. Populasi dalam penelitian ini yaitu mahasiswa akuntansi salah satu perguruan tinggi swasta di Jawa Tengah angkatan 2015 sampai 2018 yang masih aktif pada tahun 2018. Dipilihnya mahasiswa tersebut sebagai sampel karena pada akhirnya mereka akan memilih profesi yang akan ditekuninya setelah menjadi lulusan akuntansi. Teknik pengambilan sampel pada penelitian ini menggunakan metode convenience sampling.

Data yang dipakai dalam penelitian ini merupakan data primer yang sumber datanya didapatkan secara langsung dari sumber aslinya. Sumber data diperoleh melalui penyebaran kuesioner secara langsung kepada responden yang akan dikumpulkan kembali kepada peneliti. Pernyataan yang digunakan dalam kuesioner bersifat tertutup karena responden diminta untuk menjawab secara singkat sesuai dengan yang jawaban telah disediakan. Kuesioner disusun berdasarkan indikator yang ada di variabel dan menggunakan skala likert sebagai metode pengukurannya. Teknik analisis data yang digunakan dalam penelitian ini adalah analisis diskriminan. Analisis ini seperti analisis regresi linier berganda, namun perbedaanya terletak pada variabel dependennya yang harus dikategorikan

\section{Definisi Operasional Variabel}

Tabel 1. Indikator Empiris Variabel Penelitian

\begin{tabular}{lll}
\hline \multicolumn{4}{c}{ Dariabel Penelitian } \\
\hline Variabel Bebas & \multicolumn{1}{c}{ Indikator Penilaian } \\
\hline Penghargaan & Penghargaan finansial sebagai alat ukur - Gaji awal yang tinggi \\
Finansial & dalam menilai imbalan yang diperoleh - Dana pensiun \\
& atas pertimbangan jasa yang telah - Tunjangan-tunjangan \\
& diberikan karyawan. & - Potensi kenaikan gaji \\
\hline Pelatihan & Pelatihan profesional merupakan hal & - Pelatihan sebelum mulai \\
Profesional & yang berkaitan dengan peningkatan & bekerja \\
& keahlian khusus dari seorang akuntan. & - Pelatihan profesional \\
\hline
\end{tabular}




\begin{tabular}{|c|c|c|c|}
\hline & & & $\begin{array}{l}\text { Pelatihan kerja rutin } \\
\text { Pengalaman kerja }\end{array}$ \\
\hline $\begin{array}{l}\text { Pengakuan } \\
\text { Profesional }\end{array}$ & $\begin{array}{l}\text { Pengakuan profesional merupakan suatu } \\
\text { hal yang berkaitan dengan pengakuan } \\
\text { prestasi seseorang atas keberhasilannya } \\
\text { dalam melakukan pekerjaan. }\end{array}$ & $\begin{array}{l}- \\
- \\
-\end{array}$ & $\begin{array}{ll}\text { Pengakuan } & \text { apabila } \\
\text { berprestasi } & \\
\text { Kesempatan } & \text { untuk } \\
\text { berkembang } & \\
\text { Kenaikan pangkat } & \\
\text { Keahlian tertentu untuk } \\
\text { mencapai kesuksesan }\end{array}$ \\
\hline Nilai Sosial & $\begin{array}{l}\text { Nilai-nilai sosial berkaitan dengan cara } \\
\text { pandang masyarakat terhadap baik dan } \\
\text { buruknya peran dari suatu profesi } \\
\text { akuntansi. }\end{array}$ & $\begin{array}{l}- \\
- \\
-\end{array}$ & $\begin{array}{l}\text { Mendorong transparansi } \\
\text { atau keterbukaan informasi } \\
\text { Pertanggungjawaban } \\
\text { terhadap publik } \\
\text { Meminimalisir kecurangan }\end{array}$ \\
\hline Lingkungan Kerja & $\begin{array}{l}\text { Lingkungan kerja merupakan suasana } \\
\text { tempat di mana seseorang melakukan } \\
\text { pekerjaan. }\end{array}$ & $\begin{array}{l}- \\
- \\
-\end{array}$ & $\begin{array}{l}\text { Sifat kerja (rutin, atraktif } \\
\text { dan sering lembur) } \\
\text { Tingkat persaingan antar } \\
\text { karyawan } \\
\text { Tekanan kerja }\end{array}$ \\
\hline $\begin{array}{l}\text { Pertimbangan Pasar } \\
\text { Kerja }\end{array}$ & $\begin{array}{l}\text { Pertimbangan Pasar Kerja merupakan } \\
\text { cara pandang mahasiswa dalam melihat } \\
\text { tersediaanya lapangan pekerjaan dan } \\
\text { keamanan kerja. }\end{array}$ & $\begin{array}{l}- \\
- \\
-\end{array}$ & $\begin{array}{l}\text { Keamanan kerja yang } \\
\text { terjamin } \\
\text { Kemudahan mengakses } \\
\text { lowongan kerja } \\
\text { Pekerjaan yang memberikan } \\
\text { pilihan jenis pekerjaan yang } \\
\text { luas }\end{array}$ \\
\hline Personalitas & $\begin{array}{l}\text { Personalitas merupakan } r \text { karakteristik } \\
\text { psikologi dari dalam diri yang } \\
\text { menentukan serta merefleksi bagaimana } \\
\text { seseorang dalam } \\
\text { lingkungannya }\end{array}$ & $\begin{array}{l}- \\
- \\
- \\
- \\
-\end{array}$ & $\begin{array}{l}\text { Neuroticism } \\
\text { Extraversion } \\
\text { Openness to Experience } \\
\text { Agreeableness } \\
\text { Conscientiousnes } \\
\end{array}$ \\
\hline \multicolumn{4}{|l|}{ Variabel Terikat } \\
\hline $\begin{array}{ll}\text { Pilihan } & \text { Profesi } \\
\text { Akuntansi } & \end{array}$ & $\begin{array}{l}\text { Pemilihan merupakan langkah } \\
\text { mahasiswa dalam mengambil keputusan } \\
\text { terkait pekerjaan yang akan dijalani }\end{array}$ & $\begin{array}{l}- \\
- \\
- \\
-\end{array}$ & $\begin{array}{l}\text { Akuntan Pemerintah } \\
\text { Akuntan Pendidik } \\
\text { Akuntan Perusahaan } \\
\text { Akuntan Publik }\end{array}$ \\
\hline
\end{tabular}

Sumber : Data yang diolah (2019)

\section{HASIL DAN PEMBAHASAN}

\section{Gambaran Umum Responden}

Responden atau subjek penelitian ini adalah mahasiswa Progdi Akutansi Fakultas Ekonomika dan Bisnis Universitas Kristen Satya Wacana dari angkatan 2015 sampai 2018 yang masih aktif pada tahun 2018. Kuesioner yang dibagikan secara langsung kepada responden sebanyak 135 kuesioner, namun 2 kuesioner tidak dapat dipakai karena kuesioner tidak diisi secara lengkap dan adanya kesalahan dalam pengisian. Dari 135 kuesioner yang disebar didapatkan
133 sampel, namun 14 dari 133 sampel tersebut dinyatakan outlier sehingga hanya 119 sampel atau $88 \%$ saja yang nantinya dapat dianalisis lebih lanjut.

Sebagian besar responden pada penelitian ini berjenis kelamin perempuan dengan persentase $80 \%$ dan $20 \%$ sisanya responden dengan jenis kelamin laki-laki. Gambaran umum responden mengenai IPK (indeks prestasi kumulatif) yang dibagi menjadi empat bagian, diketahui bahwa sebagian besar responden memiliki IPK $\geq 3,50$ sebanyak 38 responden dengan persentase $32 \%$, responden dengan IPK antara 3,00-3,49 sebesar 44\%, responden 
dengan IPK antara 2,50-2,99 sebesar 22\%, responden dengan IPK antara 2,00-2,49 sebesar $2 \%$ dan sisanya $1 \%$ responden memiliki IPK kurang dari 2,00.

Data responden berdasarkan tahun angkatan menyatakan persebaran sampel dari angkatan 2015 dengan jumlah 29 sampel atau 24\%, angkatan 2016 dengan jumlah 28 sampel atau 24\%, angkatan 2017 dengan jumlah 27 sampel atau 23\%, dan sisanya dengan jumlah 35 atau $29 \%$ pada angkatan 2018. Jenis profesi yang paling banyak diminati responden adalah profesi akuntan internal atau perusahaan dengan persentase sebesar $59 \%$, diurutan kedua mengenai jenis profesi yang diminati responden adalah profesi akuntan pemerintah sebesar 22\%, profesi selanjutnya adalah akuntan publik sebesar $17 \%$ dan sisanya $2 \%$ dimiliki oleh profesi akuntan pendidik.

Pada pengujian data diperoleh bahwa data yang digunakan adalah valid dan reliable yang ditunjukkan dengan rhitung item-item dari ketujuh variabel besarnya melebihi rtabel atau rhitung > rtabel dengan signifikansi 5\% serta memiliki cronbach's alpha $\geq 0,60$. Penggunaan teknik analisis diskriminan mensyaratkan data yang digunakan harus bebas dari gejala multikolinearitas, bebas dari gejala heteroskedastisitas dan terditribusi normal. Data yang digunakan dalam penelitian ini telah memenuhi persyaratan bebas dari gejala multikolinearitas yang dapat dibuktikan dengan nilai Tolerance untuk masingmasing dari ketujuh variabel lebih besar dari 0,10. Sedangkan nilai VIF masingmasing tujuh variabel kurang dari 10,00.

Data juga menujukkan ketujuh variabel independen tersebut nilai signifikansinya lebih besar dari 0,05 atau (sig) >0,05 yang membuktikan bahwa tidak terjadi gejala heteroskedastisitas. Variabel independen pada penelitian ini memiliki distribusi normal multivariat yang dibuktikan dengan nilai prob $>$ Chi2 lebih besar dari 0,05 .

\section{Analisis Deskriptif Statistik}

Tabel analisis deskriptif statistik menunjukkan deskripsi data dari ketujuh variabel bebas dan satu variabel terikat yaitu profesi. Pada variabel penghargaan finansial dapat diketahui jumlah data $(\mathrm{N})$ sebanyak 119, nilai minimum sebesar 41, nilai maksimum 65 , rata-rata 54,55 dan standar deviasi 6,147. Variabel pelatihan profesional dengan jumlah data $(\mathrm{N})$ sebanyak 119 nilai minimumnya sebesar 33 , nilai maksimum 50, rata-rata 44,24 dan standar deviasi 3,927. Variabel pengakuan profesional dapat diketahui jumlah data $(\mathrm{N})$ sebanyak 119 dengan nilai minimum 42, nilai maksimum 65, rata-rata 52,71 dan standar deviasi 5,293. Variabel nilai sosial dengan jumlah data $(\mathrm{N})$ sebanyak 119 nilai minimumnya 31, nilai maksimum 50, rata-rata 42,93 dan standar deviasi 4,599. Variabel lingkungan kerja dengan jumlah data (N) 119, nilai minimum 27 , nilai maksimum 45 , rata-rata 35,13 dan standar deviasi 3,640. Variabel pertimbangan pasar kerja dengan jumlah data (N) 119 memiliki nilai minimum 27, nilai maksimum 45 , rata-rata 37,15 dan standar deviasi 3,586. Selanjutnya variabel personalitas dengan jumlah data (N) sebanyak 119 nilai minimumnya 56, nilai maksimumnya 80 , rata-rata 68,10 dan standar deviasi 5,184. Untuk variabel pemilihan profesi dengan jumlah data $(\mathrm{N})$ yang sama memiliki nilai minimum 2, nilai maksimum 5, rata-rata 3,77 dan standar deviasi 1,343.

\section{Analisis Diskriminan}

Tabel Group Statistic menerangkan bahwa dari jumlah 119 responden, 34 responden memilih profesi sebagai akuntan publik, 21 responden memilih profesi sebagai akuntan pemerintah, 62 responden memilih profesi sebagai akuntan internal atau perusahaan dan sisanya sebanyak 2 responden memilih profesi sebagai akuntan pendidik. Nilai 
rata-rata dari variabel penghargaan finansial, pelatihan profesional, pengakuan profesional dan nilai sosial pada profesi akuntan publik lebih tinggi dibandingkan dengan profesi lainnya. Sedangkan, nilai rata-rata dari variabel lingkungan kerja, pertimbangan pasar kerja dan personalitas pada profesi akuntan pemerintah lebih tinggi dibandingkan dengan profesi lainnya.

Tabel 2. Test of Equality of Group Means

Tests of Equality of Group Means

\begin{tabular}{cccccc}
\hline & Wilks' Lambda & F & df1 & df2 & Sig. \\
\hline Penghargaan Finansial &, 964 & 1,445 & 3 & 115 &, 233 \\
\hline Pelatihan Profesional &, 832 & 7,723 & 3 & 115 &, 000 \\
\hline Pengakuan Profesional &, 970 & 1,198 & 3 & 115 &, 314 \\
\hline Nilai Sosial &, 896 & 4,429 & 3 & 115 &, 006 \\
\hline Lingkungan Kerja &, 991 &, 353 & 3 & 115 &, 787 \\
\hline Pertimbangan Pasar Kerja &, 888 & 4,819 & 3 & 115 &, 003 \\
Personalitas &, 983 &, 665 & 3 & 115 &, 575 \\
\hline
\end{tabular}

Sumber : Data yang diolah (2019)

Tabel Test of Equality of Group Means menunjukkan hasil analisis untuk menguji kesamaan rata-rata variabel. Angka Wilk's Lambda berada dalam interval 0 dan 1 , jika mendekati angka 0 maka cenderung ada perbedaan dalam kelompok. Dapat diketahui dari tabel di atas angka Wilk's Lambda dari ketujuh variabel mendekati 1, yang artinya variabel-variabel tersebut kurang signifikan dalam membedakan kelompok yang memilih profesi akuntan publik, akuntan pemerintah, akuntan pendidik dan akuntan internal atau perusahaan. Variabel dikatakan dapat membedakan antar kelompok jika angka signifikan kurang dari 0,05 dan artinya hipotesis diterima. Hasil pada tabel di atas dapat disimpulkan bahwa hipotesis pada variabel pelatihan profesional, nilai sosial, dan pertimbangan pasar kerja diterima namun hipotesis pada variabel penghargaan finansial, pengakuan profesional, lingkungan keja dan personalitas ditolak.

Penelitian ini menunjukkan bahwa data yang diolah memiliki distribusi normal multivariat dan tidak adanya multikolinearitas atau hubungan antar variabel independen dapat diketahui dari penjelasan sebelumnya. Selain itu, asumsi bahwa matrik kovarian kedua kelompok adalah sama dapat dilihat di tabel 15 Test Result pada Box's $M$ yang memiliki signifikansi sebesar 0,306 atau sig >0,05. Dapat disimpulkan bahwa asumsi dari analisis diskriminan semuanya terpenuhi.

$$
\text { Sebanyak } 34 \text { responden }
$$

berdasarkan survei memilih akuntan publik namun ternyata diprediksi masuk ke dalam akuntan pemerintah 3 responden, akuntan pendidik 2 responden dan 9 lainnya masuk ke akuntan internal atau pemerintah. Sebanyak 21 responden berdasarkan survei memilih akuntan pemerintah ternyata diprediksi masuk ke dalam akuntan publik 11 responden, akuntan pendidik 1 responden dan 6 lainnya masuk ke akuntan internal atau perusahaan. Pada 2 responden yang memilih profesi akuntan pendidik ternyata 1 lainnya diprediksi masuk ke akuntan internal atau perusahaan. Sedangkan dari 62 responden berdasarkan survei memilih akuntan internal atau perusahaan ternyata diprediksi masuk ke akuntan publik 16 responden, akuntan pemerintah 4 responden dan 15 
responden masuk ke akuntan pendidik. Selain itu, tabel 15 membuktikan keakuratan model yang dipakai sebesar $49 \%$.

Berdasarkan hasil olah data menunjukkan bahwa besarnya signifikansi pada variabel pelatihan profesional sebesar 0,000 atau sig < 0,05. Hasil ini menyatakan hipotesis kedua (H2) diterima yang artinya variabel pelatihan profesional di bidang akuntansi berpengaruh terhadap pemilihan profesi akuntansi. Hasil ini konsisten dengan penelitian sebelumnya oleh Merdekawati and Sulistyawati (2011) namun bertolak belakang dengan penelitian oleh Dianati (2017). Pada variabel nilai sosial diperoleh nilai signifikansi sebesar 0,006 atau sig $<0,05$ yang artinya hipotesis keempat (H4) bahwa nilai sosial di bidang akuntansi berpengaruh terhadap pemilihan profesi akuntansi diterima. Hasil ini sejalan dengan penelitian sebelumnya oleh Merdekawati and Sulistyawati (2011) serta Talamaosandi and Wirakusuma (2017). Hal ini juga terjadi pada variabel pertimbangan pasar kerja yang menghasilkan nilai signifikansi sebesar 0,003 atau sig <0,05. Artinya hipotesis keenam (H6) bahwa pertimbangan pasar kerja di bidang akuntansi berpengaruh terhadap pemilihan profesi akuntansi diterima. Hasil ini sejalan dengan penelitian Talamaosandi and Wirakusuma (2017) namun menolak hasil penelitian oleh Merdekawati and Sulistyawati (2011).

Sebagai seseorang yang baru memasuki dunia kerja, mahasiswa mempertimbangkan adanya pelatihan sebelum bekerja sangat diperlukan karena tidak cukup hanya berbekal pengetahuan selama di perguruan tinggi. Adanya pelatihan kerja yang rutin juga dapat meningkatkan kemampuan dan menambah pengalaman kerja seorang akuntan. Keputusan pemilihan profesi sebagai akuntan oleh mahasiswa dikarenakan profesi ini memberikan jenis pekerjaan yang luas. Bukan hanya jenis pekerjaannya saja tetapi kemudahan dalam mengakses lowongan juga menjadikan profesi akuntan ini dipertimbangkan. Namun, hal yang ditakutkan terjadi setelah mendapatkan profesi yang diinginkan adalah pemutusan hubungan sepihak atau secara massal oleh perusahaan. Untuk itu mahasiswa mengharapkan adanya keamaan kerja yang terjamin serta terhindar PHK. Akuntan merupakan pihak yang memiliki tanggungjawab terhadap informasi yang disampaikan. Masyarakat percaya bahwa akuntan sangat berperan dalam mendorong transparansi laporan keuangan suatu perusahaan serta meminimalisir kecurangan-kecurangan yang kemungkinan akan terjadi pada setiap perusahaan.

Temuan terhadap ketiga faktor di atas yaitu pelatihan profesional, nilai sosial dan pertimbangan pasar kerja menunjukkan bahwa faktor non finansial lebih berpengaruh terhadap pemilihan profesi akuntan dibandingkan dengan faktor finansial. Dalam hal ini faktor finansial relatif bepengaruh, namun tidak menutup kemungkinan juga membutuhkan status atau pengakuan. Pada faktor pelatihan profesional memberikan status khusus bahwa sebagai seorang akuntan yang memiliki keahlihan khusus pada bidang profesi yang dijalaninya. Faktor nilai sosial memberikan status yang lebih tinggi seperti sebagai seorang akuntan akan dipandang lebih baik di lingkungan masyarakat. Faktor pertimbangan pasar kerja juga memberikan status bahwa setelah menjadi seorang akuntan tentunya juga akan terhindar dari sebutan sebagai pengangguran.

Empat dari tujuh variabel ini memberikan hasil signifkansi yang nilainya lebih dari 0,05 yang menandakan 
hipotesis keempat variabel tersebut ditolak. Hipotesis pertama (H1) yaitu penghargaan finansial dengan nilai sig $0,233>0,05$ artinya bahwa penghargaan finansial di bidang akuntansi tidak berpengaruh terhadap pemilihan profesi akuntansi. Hasil ini mendukung penelitian sebelumnya oleh Merdekawati and Sulistyawati (2011) akan tetapi bertolak belakang dengan hasil penelitan Dianati (2017). Hipotesis ketiga (H3) yaitu pengakuan profesional dengan nilai sig $0,314>0,05$ artinya pengakuan profesional di bidang akuntansi tidak berpengaruh terhadap pemilihan profesi akuntansi. Hipotesis kelima (H5) yaitu lingkungan kerja dengan nilai sig 0,787 > 0,05 artinya lingkungan kerja di bidang akuntansi tidak berpengaruh terhadap pemilihan profesi akuntansi. Selanjutnya, hipotesis ketujuh $(\mathrm{H} 7)$ yaitu personalitas dengan nilai sig $0,575>0,05$ artinya personalitas tidak berpengaruh terhadap pemilihan profesi akuntansi.

Temuan mengenai keempat penolakan hipotesis di atas menujukkan bahwa finansial bukan semata-mata yang dicari oleh seorang akuntan. Gaji awal yang tinggi, adanya tunjangan dan dana pensiun bukan dasar pertimbangan mahasiswa dalam memilih profesi akuntan. Penyebabnya mahasiswa lebih berfikir untuk mengembangkan keterampilan yang dimiliki. Personalitas yang menunjukkan respon seseorang terhadap lingkungannya tidak mempengaruhi keputusan mereka dalam memilih pekerjaan. Lingkungan kerja yang rutin, sering lembur, adanya persaingan antar karyawan dan dituntut bekerja dibawah tekanan merupakan hal yang wajar dan biasa terjadi didunia kerja. Selain itu pengakuan apabila sebagai seorang akuntan yang berprestasi bukan hal yang harus dilakukan, cukup diberikan penghargaan saja. Mahasiswa berfikir apabila hal tersebut dilakukan akan berdampak pada berubahnya sikap karyawan yang berpikiran bahwa statusnya lebih tinggi dibandingkan karyawan lain dan akan menganggap karyawan lain tidak lebih pintar dari dirinya.

\section{SIMPULAN DAN SARAN}

\section{Kesimpulan}

Berdasarkan pengolahan data yang telah dilakukan serta pembahasan mengenai hasil tersebut, dapat ditarik kesimpulan bahwa pelatihan profesional, nilai sosial dan pertimbangan pasar kerja di bidang akuntansi berpengaruh terhadap pemilihan profesi akuntansi. Sedangkan penghargaan finansial, pengakuan profesional, lingkungan kerja dan personalitas di bidang akuntansi tidak berpengaruh terhadap pemilihan profesi akuntansi. Dari hasil tersebut juga didapatkan temuan bahwa finansial bukan hal yang paling dicari oleh mahasiswa, namun mahasiswa juga menginginkan adanya status atau pengakuan atas profesi yang dipilihnya. Selain itu, dapat diketahui persebaran profesi akuntansi yakni akuntan internal atau perusahaan memiliki jumlah terbanyak kemudian disusul oleh akuntan publik, akuntan pemerintah, dan persebaran profesi paling sedikit pada akuntan pendidik.

\section{Keterbatasan}

Penelitian ini hanya terbatas pada satu instansi pendidikan. Sampel yang digunakan tergolong kecil yaitu sebanyak 119 dengan teknik pengambilan sampel menggunakan metode convenience sampling yang hanya berdasarkan asas kemudahan. Pada penelitian ini juga menggunakan faktor-faktor pada penelitian sebelumnya untuk diuji dengan beberapa pengembangan indikator di dalamnya.

\section{Saran}

Penelitian ini berguna untuk pemerintah sebagai regulator bisa mengantisipasi kekurangan akuntan 
profesional di masa mendatang. Sedangkan untuk pelaksana pendidikan tinggi di bidang akuntansi dapat mengembangkan inovasi serta perbaikan dalam proses pembelajaran guna meningkatkan minat mahasiswa terhadap profesi akuntan. Pada penelitian selanjutnya diharapkan ruang lingkup penelitian tidak terbatas pada Universitas Kristen Satya Wacana saja, namun mencakup semua perguruan tinggi yang ada di Kota Salatiga. Penggunaan sampel sebaiknya lebih dari penelitian ini dengan metode selain convenience sampling, sehingga akan lebih banyak sampel yang dapat digunakan. Untuk penelitian mendatang sebaiknya menambahkan faktor-faktor lain agar hasil yang didapatkan lebih akurat dan lebih up to date.

\section{DAFTAR PUSTAKA}

Chan, Andi Setiawan. 2012. “Analisis Faktor-Faktor Yang Mempengaruhi Pemilihan Karir Menjadi Akuntan Publik Oleh Mahasiswa Jurusan Akuntansi." Jurnal Ilmiah Mahasiswa Akuntansi 1(1): 53-58.

Dianati, Amalia Nur. 2017. "Faktor-Faktor Yang Mempengaruhi Minat Mahasiswa Akuntansi STIE Perbanas Surabaya Dalam Pemilihan Karir Sebagai Akuntan Publik." : 1-14. http://eprints.perbanas.ac.id/id/eprint/2596.

Dwi, Christine, and Arif Setiawan. 2012. "Pengaruh Persepsi Mahasiswa Akuntan Mengenai Lingkungan Kerja Auditor Terhadap Pilihan Karirnya Sebagai Auditor Di KAP.” Jurnal Ilmiah Akuntansi: 1-13.

Harianti, Sarli Siska. 2017. "Pengaruh Penghargaan Finansial, Gender Dan Lingkungan Kerja Terhadap Minat Menjadi Akuntan Pemerintah.” Jurnal Akuntansi 5(1).

Hudayati, Ataina. 2002. "Perkembangan Penelitian Akuntansi Keperilakuan: Berbagai Teori Dan Pendekatan Yang Melandasi." JAAI 6(2): 8196.

IAI. 2016. "Kejar Ketertinggalan Akuntan Di ASEAN IAI Siapkan Sertifikasi Dan Penataan Profesi." IAI. http://iaiglobal.or.id/v03/beritakegiatan/detailarsip-895 (September 23, 2018).

McCrae, Robert R., and Paul T. Costa. 1989. "Reinterpreting the Myers-Briggs Type Indicator From the Perspective of the Five-Factor Model of Personality." Journal of Personality 57(1): 17-40.

Merdekawati, Dian Putri, and Ardiani Ika Sulistyawati. 2011. "Faktor-Faktor Yang Mempengaruhi
Pemilihan Karir Akuntan Publik Dan Non Akuntan Publik." Jurnal Ilmu Ekonomi ASET 13(1): 43.

Munjin, Ahmad. 2018. "RI Masih Butuh 452 Ribu Akuntan Profesional." Inilahcom. http://m.inilah.com/news/detail/2470020/wowri-masih-butuh-452-akuntan-profesional.

Nasyroh, Muslim, and Rinandita Wikansari. 2017. "Hubungan Antara Kepribadian (Big Five Personality Model) Dengan Kinerja Karyawan." Jurnal Ecopsy 4(1): 10-16.

Purwati, Atiek Sari, and Yeni Yunita Sari. 2015. "Persepsi Mahasiswa Akuntansi Terhadap Pemilihan Karir." Jurnal Kajian dan Pengembangan Akuntansi 5(2): 123-51.

Rahayu, Sri, Eko Arif Sudaryono, and Doddy Setiawan. 2003. "Persepsi Mahasiswa Akuntansi Mengenai Faktor-Faktor Yang Mempengaruhi Pemilihan Karir." In Jurnal Dan Prosiding Simposium Nasional Akuntansi VI, Surabaya, 821-46.

Ramdhan, Muhamad Radinal, and Mimin Widaningsih. 2017. "Analisis Persepsi Mahasiswa Akuntansi Mengenai Faktor-Faktor Yang Mempengaruhi Pemilihan Karir Sebagai Akuntan.” Jurnal SIKAP (Sistem Informasi, Keuangan, Auditing Dan Perpajakan) 1(1): 134.

Riyanto, Rudy Arif. 2015. "Analisis Faktor-Faktor Yang Mempengaruhi Minat Mahasiswa Akuntansi Berkarir Menjadi Akuntan Publik.” http://eprints.ums.ac.id/34761/1/NASKAH PUBLIKASI.pdf.

Robbin, Stephen P. 2001. Perilaku Organisasi, Konsep, Kontroversi Dan Aplikasi. Jakarta: Prenhalindo.

Senjari, Richa. 2016. "Pengaruh Motivasi, Lingkungan Kerja Dan Nilai Sosial Terhadap Minat Mahasiswa Akuntansi Dalam Memilih Karir Sebagai Akuntan Publik." Jurnal Online Mahasiswa Fakultas Ekonomi Universitas Riau 3(1): 133-47.

Senoadi, Yohanes Prabowo. 2015. "Faktor-Faktor Yang Mempengaruhi Pemilihan Karir Lulusan Sarjana Menjadi Akuntan Publik." Media Riset Akuntansi, Auditing \& Informasi 15(2): 171-94.

Siskayani, Ni Made, and Putu Wenny Saitri. 2013. "Analasis Faktor-Faktor Yang Mempengaruhi Mahasiswa Akuntansi Dalam Pemilihan Karir Menjadi Akuntan Publik.” Jurnal Riset Akuntansi 7(2): 189-97.

Sudarsono, Bramasto. 2014. "Analisis Persepsi Mahasiswa Akuntansi Terhadap Faktor-Faktor Yang Mempengaruhi Pemilihan Karir.” : 43. https://www.academia.edu/34593211/ANALISI S_PERSEPSI_MAHASISWA_AKUNTANSI_ TERHADAP_FAKTOR-

_FAKTOR_YANG_MEMPENGARUHI_PEM ILIHAN_KARIR_Disusun_Oleh.

Suyono, Nanang Agus. 2014. "Analisis Faktor-Faktor Yang Mempengaruhi Pemilihan Karir Sebagai Akuntan Publik." Jurnal Penelitian dan Pengabdian Kepada Masyarakat: 69-83.

Talamaosandi, Ni Komang Putri Sari, and Made Gede Wirakusuma. 2017. "Pengaruh Lingkungan Kerja, Nilai - Nilai Sosial, Pertimbangan Pasar 
Kerja, Dan Personalitas Pada Pemilihan Karir Akuntan Publik." Jurnal Riset Akuntansi 19(1): $1-26$.

https://ojs.unud.ac.id/index.php/Akuntansi/articl e/view/21035/18319\%0A.

Yanti, Novrika. 2017. "Faktor-Faktor Yang Mempengaruhi Mahasiswa Akuntansi Dalam Pemilihan Karir Menjadi Akuntan Public (Studi
Empiris Pada Mahasiswa Akuntansi UR, UIN SUSKA, Di Pekanbaru Dan UNP, UNAND Di Padang." Jurnal Akuntansi 1(2001).

Yusran, Rio Rahmat. 2017. "Analisis Faktor Yang Mempengaruhi Minat Mahasiswa Terhadap Pemilihan Karir Akuntan/Non Akuntan.” Jurnal Akuntansi 5(2): 203-12. 